\title{
A Nemzeti Ujság politikai állásfoglalása és a márciusi fordulat, 1845-1848
}

\author{
Political standpoint of the Nemzeti Ujság and its radical turning, \\ $1845-1848$
}

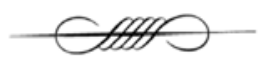

\begin{abstract}
The aim of my study is to show a Hungarian conservative newspaper's political principles during the second half of the 1840s. The Nemzeti Ujság was undergoing massive changes under the direction of Sándor Lipthay between the last two Hungarian diets of the Reform Era. The events of the examined period had serious effects upon those changes. For instance the moderate censorship; the diet of 1843/44 and the resulting opposition of the absolutist governemnt of Wien; furthermore the foundation of the Hungarian Conservative Party. Nevertheless the Revolution of 1848 had the most significant effect upon the face of the newspaper. The attitude of the journal had been continuously diverging from the official conservative standpoints. The distancing, nevertheless, was not permanent; occasionally it slowed down or began accelerating. After the Hungarian revolution the Nemzeti Ujság was the first newspaper that started supporting the new regime. This radical turn was utterly striking for other journals too.
\end{abstract}

\section{KEYWORDS}

revolution, conservatism, Hungary, reform era, press

DOI 10.14232/belv.2019.2.7 https://doi.org/10.14232/belv.2019.2.7

Cikkre való hivatkozás / How to cite this article: A Nemzeti Ujság politikai állásfoglalása és a márciusi fordulat, 1845-1848. Belvedere Meridionale 31. évf. 2. sz. 123-135. pp.

ISSN 1419-0222 (print) ISSN 2064-5929 (online, pdf)

(Creative Commons) Nevezd meg! - Így add tovább! 4.0 (CC BY-SA 4.0)

(Creative Commons) Attribution-ShareAlike 4.0 International (CC BY-SA 4.0)

www.belvedere-meridionale.hu 


\section{A NeMZeti UjSÁG ALAPELVEi 1845 És 1847 KöZötT}

A reformkorra, illetve az 1848-as magyar forradalomra elsősorban - és nem teljesen érdemtelenül úgy tekintünk, mint a magyar liberális ellenzék abszolutista hatalom elleni magányos harcára. Mindemellett a közel sem egységes, konzervatívnak nevezett erők sem zárkóztak el a reformok és a haladás elől, sőt nem egy esetben sürgették ezeket a reformokat.

Az 1839/40-i évi országgyülés után az ellenzék és a kormány is felismerte, hogy a sajtó fejlődése új szakaszába lépett, ráadásul a kormány számításon alapuló kezdeményezésére jóval enyhébb cenzúra eljárás érvényesült a hazai hírlapok esetében. ${ }^{1}$ A bécsi kormányzat ettől azt remélte, hogy a szabadabb sajtó egyfajta szelepként fog müködni, és csökkenti a liberális ellenzék követeléseinek radikalizmusát. ${ }^{2}$ Ezt használta ki többek között Kossuth Lajos Pesti Hirlapja is, mely a vezércikk müfajának meghonosításával nem csak a hazai hírlapirodalmat reformálta meg, hanem ennek köszönhetően jelentős mértékben kiszélesítette olvasóközönségét. A liberális ellenzék sajtóorgánumává váló lap mintájára döntött úgy a Nemzeti Ujság is, hogy nézeteinek erőteljesebb hangot ad a lap hasábjain. ${ }^{3}$

A Nemzeti Ujság az 1806-ban, Kultsár István által alapított Hazai Tudósitások, majd 1808-tól Hazai és Külföldi Tudósitások elnevezésű politikai hírlap jogutódjának tekinthető. Nevét 1840-ben változtatták Nemzeti Ujságra, melyre a lap munkatársai és a közvélemény konzervatív és katolikus orgánumként tekintett. Az 1840-es évek első felében a lap szerkesztői nem értek fel Kossuth tehetségéhez, így jóval kisebb hatást gyakoroltak a közvéleményre, mint a Pesti Hirlap lapszámai. 1845 januárjában azonban egy új szerkesztő, Lipthay Sándor került a lap élére. Az ő tehetsége sem szárnyalta túl a korszak jelentős íróéit, de az 1840-es években ő volt a lap legtöbbre hivatott szerkesztője. Írásomban a Nemzeti Ujságnak az ő nevével fémjelzett időszakát vizsgálom meg.

Lipthay Sándor nemesi származású vagyonos pesti ügyvéd volt. ${ }^{4}$ Érdeklődése nem csak a sajtóra terjedt ki, ezért elsősorban nem jövedelemforrásként tekintett hírlapi munkájára. Jogi diplomája megszerzése után a konzervatív csoportosulás egyik vezéralakja lett Pesten, annak szervezőmunkájából tevékenyen kivette a részét. 1845 októberében az ő kezdeményezésére jött létre a Közhasznú Gyülde. ${ }^{5}$ A pártatlanságát hangsúlyozó Gyülde célja az volt, hogy ellensúlyt képezzen az ellenzéki törekvésekkel szemben, ennek megfelelően főként konzervatív beállítottságú tagokból állt, valamint szoros kapcsolatban állt a Nemzeti Ujsággal. A lap gyakorlatilag e konzervatív kör hivatalos lapja volt, szerkesztőgárdája pedig jórészt a Gyüldéből került ki. ${ }^{6}$ Társszerkesztőként, de Lipthaynak alárendelt szerepkörben müködött közre a lapnál a szintén nemesi származású ügyvéd, Illucz Oláh János. ${ }^{7}$

Az 1843/44-i, a sikertelen országgyülés után a bécsi kormányzat az adminisztrátori rendszer által igyekezett minél több hívet szerezni magának, míg a liberális ellenzék passzív

\footnotetext{
${ }^{1}$ DezsénYi 1941. BÉnYei 1994. 68-69., DöBÖR 2018. 71-73.

2 BuZINKAY 2017.

${ }^{3}$ Dezsényi 1941.

${ }^{4}$ SzINNYEI 1897.

5 Velkey 1998.

${ }^{6}$ DEÁK 2010.

${ }^{7}$ KÓKAY 1978.
} 
ellenállásba vonult. Ráadásul Kossuth Lajos többé már nem volt a Pesti Hirlap főszerkesztője, helyét a centralisták vették át. ${ }^{8}$

Lipthay Sándor szerkesztőségének első három évében markáns változás nem figyelhető meg a konzervatív lap politikai állásfoglalását illetően. 1845. január 2-i beköszönő cikkében az új főszerkesztő megjelölte az előző diéta sikertelenségének okát: Magyarország közjogi állásának tisztázatlanságát. Kijelentette, az új Nemzeti Ujság „, a stabilitás elve szerint müködö, arisztokrata, progressiv lap lesz". ${ }^{9}$

Lipthay szerint a dicső jövő fő biztosítéka e közjogi állás tisztázása. Fontos az alkotmányos élet biztosítása, azonban az alkotmányosság a magyarok számára Lipthay szerint még ismeretlen volt. A sajtó feladata éppen az volt, hogy a nemzetet megismertesse az alkotmányos politikai élettel. A magyar politikai elit számára célként olyan követutasítások kidolgozását jelölte ki a következő országgyűlésre, melyek az általa ismertetett tiszta elvek alapján készülnek el. Erősen kritizálta a centralizmust és a népképviselet elvét. ${ }^{10} \mathrm{E}$ kritika 1847 -ig folyamatosan visszatért a hírlap különböző számaiban.

A lap szerint a magyar politikai csoportosulások csak külső megjelenésükben tértek el egymástól, de lényegük megegyezett, például abban, hogy maguknak akarták a haladás és fejlődés dicsőségét. A megoldást Lipthay véleménye szerint egy középutas párt megalakítása jelentette volna, mely stabilitást hozott volna a politikai életbe.

E középutas párt felállításának a gondolata 1846-ban is megjelent a lapban, miután Lipthay úgy döntött, közzé teszi politikai programját. A Politikai programm néven, 1846 nyarán közzé tett cikksorozat kitért a Magyarország, és a birodalom nyugati fele közötti közjogi viszonyra is. Leszögezte, a „magyar kormánynak” a magyar nemzetet kell képviselnie, de szoros kapcsolatot kell ápolnia a birodalmi vezetéssel. ${ }^{11}$ Ennek a lap szerint elsődleges oka, hogy Ausztria és Magyarország kapcsolata Európa ügye lett, hiszen a birodalom Magyarországgal együtt tartotta fenn a kontinentális egyensúlyt. Éppen ezért a magyarországi kormányzati rendszer minden esetleges változtatását előzetesen egyeztetni kell Béccsel. Ezt alapul véve Lipthay véleménye szerint Magyarország így sohasem lehet teljesen független Ausztriától, de függetlenségét a körülményekhez mérten a lehető legnagyobb fokra kell juttatni.

Ebben a cikksorozatban is tetten érhető a népképviseleti eszme és a centralizmus bírálata, de már kissé felpuhult változatban. A cikkíró kiemelte, nem céljuk a képviseleti eszme támadása, mert az alapvetően hasznos és jó, sőt, a kor szükségévé vált. Ennek ellenére a politikai élet fejletlensége miatt Magyarországon nem lenne működőképes a rendszer. Egyértelműen támadta viszont a felelős kormányzás liberálisok által propagált eszméjét. Felelős kormányzásra ugyanis valóban szükség van, de felelősség alatt mindössze erkölcsi felelősséget értett. Konzervatív lap lévén kissé zavarba ejtő lehet a cikksorozat egyik számában olvasható mondat: „,Jelszavunk a liberalismusnak azon fönséges és tiszta neme, melly minden lépten a jövő érdekeit biztositni, $s$ a jelenét kimélni törekszik!'” ${ }^{12}$ Ez mutatja, hogy a haladás elvét elfogadták, és nem eszmék, hanem praktikus szempontok alapján alkották meg programjukat.

\footnotetext{
${ }^{8}$ Gergely 2003.

${ }^{9}$ Nemzeti Ujság 1845. január 5. Politikai pártok.

${ }^{10}$ Nemzeti Ujság 1845. január 2. Irány és tájékozás.

${ }^{11}$ Nemzeti Ujság 1846. július 14. Politikai programm.

${ }^{12}$ Nemzeti Ujság 1846. július 2. Politikai programm.
} 
A konzervatívok 1846 nyarán elérkezettnek látták az időt arra, hogy elkezdjék egy saját párt szervezését. A készülő program főbb elemeit a Budapesti Hiradó kezdte tárgyalni, míg a konzervatív találkozók rendszeressé váltak a Gyüldében. A Konzervatív Párt megalapítására végül 1846. november 12-én került sor. A konzervatív program elsősorban a Konzervatív Párt közéleti elhelyezkedését határolta körül, fő céljuknak pedig az alsótáblai többség kialakítását tekintették a következő országgyülésre. A szervezési munkálatok utolsó fázisából a Nemzeti Ujság is igyekezett kivenni a részét. Ennek érdekében látott napvilágot a hírlapban A conservativ ügy körüli teendők című cikksorozat 1846. október 8. és 23. között.

A párt megalakulásával Lipthay Sándor szerint a konzervatív ügy második stádiumába lépett. Azonban szerinte a konzervatívok csak akkor maradhatnak a kormány támogatói, amennyiben az az akkori, reformtámogató irányvonalát megtartja. A reform és a változás ugyanis elodázhatatlan. Ennek a változásnak békés úton kell megtörténnie, ezért is elengedhetetlen a konzervatívok kormánypárttá alakulása. Visszautasította az ellenzékiek azon vádját, miszerint a magyar kormányzati rendszer igényeit kiszolgáló csoportosulás lennének. Mind ezek ellenére alapjaiban vetette el a két párt közötti együttmüködés lehetőségét. E felfogás szerint „,az ellenkezö pártnak soha sincs igazsága, soha sem lehet igazsága". ${ }^{13}$

1847 tavaszán-nyarán, április 22. és augusztus 1. között egy meglehetősen zavarba ejtő cikksorozat jelent meg az újság hasábjain, Nyilt levelek Lipthay Sándorhoz címmel. Lipthay Sándor 1847 tavaszán betegszabadságra vonult maglódi birtokára. Az ismeretlen szerző tollából származó vezércikkek „egy conservativ” álnév alatt jelentek meg, és a főszerkesztő beleegyezésével láttak napvilágot. Noha Lipthay előre leszögezte, a benne foglaltaktól elhatárolódik, kijelenthető, hogy a lap akkor már nem állt teljes mellszélességgel a magyar kormányzat mellett, és nem riadt vissza annak bírálatától sem. A cikksorozat írója elmarasztalta a magyar kormányzatot, mert az nem sürgette már jóval korábban egy kormánypárt létrehozását. Erre szerinte már 1840-ben szükség lett volna, és akkor elkerülhető lett volna a pártvitáktól hangos, de érdemben tétlen országgyülések idő előtti berekesztése. A rossz kormányzati adminisztráció következtében pedig még ezeken az országgyüléseken sem sikerült kiharcolni a kormányzatot támogatók többségét az alsótáblán.

A cikksorozat nagy port kavart a megjelenésekor, sőt, a tizenegy részes cikksorozat utolsó vezércikke meg sem jelenhetett a lapban. A cenzúrahivatal akkori vezetője, Szőgyény-Marich László emlékirataiban leírta, a Nemzeti Ujság több munkát adott nekik, mint a liberális és ellenzéki sajtótermékek összesen. ${ }^{14}$

Lipthay és a Nemzeti Ujság tehát főként csak a képviseleti rendszerről, valamint Magyarország birodalmon belüli közjogi állásáról értekezett 1845 és 1847 között a hírlap hasábjain. 1847 folyamán azonban a lap több cikkben, illetve cikksorozatban is részletesen foglalkozott az úrbérváltság és a közteherviselés kérdésével, négy szerző, Lipthy Sándor, Csiki Emánuel, valamint a porosz abszolútizmus feltétlen hívének és a nagybirtok elszánt védelmezőjének számító Kállay Ferenc tollából, míg egy vezércikk névtelenül jelent meg a lapban.

Alapvetően az összes írás megegyezik abban, hogy mind a közteherviselést, mind a teljes kárpótlással történő jobbágyfelszabadítást elkerülhetetlennek véli, azonban csak jelentős előkészületek után, hiszen - Lipthay szavaival élve - a közbirodalmi és a nemzeti viszonyok még

\footnotetext{
${ }^{13}$ Nemzeti Ujság 1846. október 23. A conservativ ügy körüli közvetlen teendők.

${ }^{14}$ Szőgyény-Marich László országbíró emlékiratai III. fejezet
} 
nem elég fejlettek az említett törvények végrehajtásához. Mindhárom szerző következetesen elveti a feltétlen adózás és az örökváltság együttes megvalósítását is, mivel szerintük e két reformjavaslat nem kapcsolható össze, azokat külön-külön kell megoldani. ${ }^{15}$

Lipthay szerint, aki cikkét Kossuth Hetilapban megjelent, hasonló témájú írása polémiájának szánta, elsősorban nem politikai, hanem gazdasági előnyei vannak az örökváltságnak, hiszen végrehajtása elősegítené a magyar ipar és a közlekedési hálózat fejlődését. A végrehajtását viszont csak királyi biztosok révén és fokozatosan haladva fogadná el. ${ }^{16}$

Kállay véleménye szerint az ország felkészületlensége miatt az önkéntes örökváltság bevezetése nem hozta el a várt eredményt. A magát megváltani akaró jobbágy esetenként uzsorapénzből szabadult meg az úrbéri terhektől, ahol pedig végbement a megváltás, ott a zsidóság vette át a földesúr szerepét. Így az előkészületekkor mindenekelőtt a jogsértéseket kell kiküszöbölni. ${ }^{17}$

Csiki Emánuel az előbbi két cikkíróval szemben azt állította, hogy a jobbágyság 99\%-a nem is akarta magát megváltani, tehát már ezért sem érdemes sürgetni az örökváltságot. Sőt, szerinte a nemesség nem is adómentes Magyarországon, hiszen az ,, a közállomány terheiben nagy mértékben részesül”. Kossuthot és az ellenzéket a nemesség népszerütlenítésével vádolja, akik demagógiát, anarchiát, diktatúrát, polgárháborút és elnyomást hoznának az ország számára. Ő a megoldást - a bécsi udvar által is erősen propagált - belső vámok felszámolásában és a közlekedési eszközök fejlesztésében látta. ${ }^{18}$

A névtelenül megjelent vezércikk írója is úgy gondolja, az örökváltság vagy éppen az ősiség módosítása szükséges, de nem időszerű. Szerinte a reformoknak a status quoból, tehát abból kell kiindulniuk, hogy Magyarország egy birodalom része, ezért minden döntés előtt az összbirodalom érdekeit kell szem előtt tartani. ${ }^{19}$

Arról, hogy pontosan milyen előkészületeket szükséges megtenni az örökváltság végrehajtása elött, Kállay Ferenc írt részletesebben. Mindenekelőtt az ősiséget kell módosítani, de a módosítás előtt is szükség van lépésekre: hitelintézetek és állandó törvényszékek felállítására, a bírói eljárás és a pereskedés szabályozására, a telekkönyvek bevezetésére és a „zsidóügy” szabályozására. Ha mindez megvan, akkor meg kell határozni az örökváltság kárpótlásának összegét, össze kell írni a megváltandó földeket, és be kell vezetni az örök haszonbér rendszerét. ${ }^{20}$

1847 végétől kezdődően már konkrétabb események kerültek a hazai lapok célkeresztjébe. 1847 novemberében összeült az újabb országgyülés, néhány héttel később pedig véres harcok bontakoztak ki a kontinens több régiójában a lakosság, illetve az abszolutista hatalmak katonasága között. Európában 1848 elején gazdasági és társadalmi feszültségek egyaránt közrejátszottak a forradalmi hullám megindulásában. ${ }^{21}$ Az Itáliából kiinduló és Párizsban döntő lökést kapó forradalmi hullám Magyarországot is elérte. A pesti mozgalom nyomán néhány

\footnotetext{
${ }^{15}$ Nemzeti Ujság 1847. január 1. Adó és urbérváltság.

${ }^{16}$ Nemzeti Ujság 1847. január 7. Adó és urbérváltság.

${ }^{17}$ Nemzeti Ujság 1847. május 20. Örökváltság.

${ }^{18}$ Nemzeti Ujság 1847. február 18. Ábránduljunk ki honfiak!

${ }^{19}$ Nemzeti Ujság 1847. március 9. Szózat.

${ }^{20}$ Nemzeti Ujság 1847. május 28., június 1., június 8. Örökváltság.

${ }^{21}$ Diószegi István 1997.
} 
nap alatt megvalósította azt, amiért évtizedek óta küzdött a liberális ellenzék a rendi országgyüléseken: az ország polgári átalakulásának elindítását. Maguk az ellenzék vezetői sem remélték e folyamat ilyen ütemű és mértékű sikerét; a kormánypárti és konzervatív csoportok egyértelmű vereséget szenvedtek. A vér nélküli pesti forradalom azonban ezzel még nem ért véget, az új rendszerhez pedig minden politikai csoportosulás egyedi módon igyekezett alkalmazkodni.

\section{A Nemzeti UjSÁg ÉS A PeSti FORRAdalom}

A sikeres pesti forradalom következtében a konzervatívoknak szembe kellett nézniük saját eszméik bukásával. Míg vezető orgánumuk, a Budapesti Hiradó szerkesztőt váltott, a Nemzeti Ujság továbbra is Lipthay Sándor szerkesztésében jelent meg, azonban a forradalom mellé állva üdvözölte annak minden vívmányt. Sőt, a Nemzeti Ujságban jelent meg a március 15-i pesti események első leírása, a lap közölte először a 12 pontot és Petőfi Nemzeti Dalát. Sőt, még a megalakuló új magyar kormány beiktatása előtt közzé tett egy „kívánságlistát” a leendő miniszterekről, soraikban csupa liberális vezető személyiséggel. ${ }^{22}$ A radikális fordulatra mindenekelőtt magyarázatot kellett adnia olvasóközönségének.

Lipthay kijelentette, hogy habár a változások jóval radikálisabb módon mentek végbe, mint azt remélték, de örömét fejezte ki a végkimenetelt illetően. „Forradalmunknak isteni bélyege van ... szebbet, dicsőbbet, a világ soha nem látott (...) Lehetetlen, hogy ne legyen rajta isten áldása!'”23 Úgy vélte, az átalakulás Isten elrendelése szerint ment végbe: ,, a nép szavában Isten nyilatkozik”. ${ }^{24}$ Kijelentése szerint az isteni gondviselés és az emberek közös munkája révén azonban nem az ország politikai hozzáállása változott meg, hanem helyreállt az ország függetlensége. A lap tehát érzékelte az események korszakalkotó jelentőségét, és próbálta azt valamilyen módon befogadni és magáévá tenni.

A szerkesztő úgy vélte, a kialakult helyzet nemzeti egység által jött létre, amely az új, felelős magyar kormányban öltött testet. Az új végrehajtó hatalmat minden egyes állampolgárnak támogatásáról kell biztosítania, ugyanis ,ellene izgatni s ellenszenvet gerjeszteni a legkárhozatosabb politicai lépés, valóságos fölhivás a polgári háborura, árulás a haza, a trón, a dynastia ellen. ' ${ }^{25}$ A nemzeti egység felbomlása a kormány bukását idézné maga után, így a sajtó új feladata az első felelős magyar kormány népszerűsítése lett, hirdette. A lap szerint éppen ezért a korábbi konzervatív politikai tábor megszűnt, most már egyedül a kormány helyzetét kell konzerválni. Politikai csatározásoknak nincs helye többé.

A lap e politikája az új sajtótörvény országgyülési tárgyalása során is előtérbe került. A törvény tervezete lényegesen alul múlta a korábbi várakozásokat, és jelentős kauciót helyezett kilátásba új lapok indításánál. ${ }^{26} \mathrm{~A}$ pesti ifjúság a törvénytervezet szövegét a Duna-parton elégette, mely cselekedetükkel nyíltan szembe fordultak a diétával. Habár a törvény tervezetével a Nemzeti

\footnotetext{
${ }^{22}$ Nemzeti Ujság 1848. március 17. Kiket kiván a nemzet felelös ministereknek?

${ }^{23}$ Nemzeti Ujság 1848. március 28. Inditvány.

${ }^{24}$ Nemzeti Ujság 1848. március 21. Magyarország és Erdély.

${ }^{25}$ Nemzeti Ujság 1848. március 19. Batthyány-Kossuth ministerium.

${ }^{26}$ Nemzeti Ujság 1848. március 24. Figyelmeztetésünk.
} 
Ujság sem volt elégedett, a márciusi ifjak tettét mélységesen elítélte, és ismét felszólított az új rendszer feltétel nélküli támogatására, és a rend megőrzésére. Lipthay szerint ugyanis: „,Mozgalmi időszakban, bármi békes színt viseljen magán az események külsö menetele, közel esik mindig a látszatos nyugalom állapotához a féktelen eröszak lehetö kitörése. ${ }^{\text {'7 }}$ A rend a szabadság lelke, vallotta. Hasonlóképpen fogadták az 1848. március 28-i királyi leirat hírét is a lapnál. Egyértelmű volt, hogy Metternich bukása után Bécsben még mindig a kamarilla kormányoz, mely vissza akarta vonni a forradalom útján elért engedményeket Magyarországon. A királyi leirat az első lépésnek volt tekinthető ezen az úton.

A leirat ugyanis nem hagyta jóvá a nádor teljhatalmú helytartói jogkörét, megtartotta a Kancelláriát, az új magyar minisztérium jogkörét a Helytartótanácséval tette egyenlővé, tehát meghagyta a király kinevezési, cím- és birtokadományozási jogát. A magyar pénzügyeket a királyi kincstár alá, míg a hadsereget a magyar király hatásköre alá sorolta, amivel gyakorlatilag lehetetlenné tette az önálló magyar pénzügy és hadügy megalakítását. Ezek mellett elrendelte az úrbéri viszony megszüntetéséről szóló törvényjavaslat újra tárgyalását, arra hivatkozva, hogy a földbirtokosok érdekei nincsenek kellőképpen védve az elkészült javaslatban. A királyi leirat híre csalódottságot és ingerültséget váltott ki az új rendszer képviselőiből és támogatóiból, a fôvárosban pedig félő volt, a vérnélküli forradalom ideája szertefoszlik. Csalódottságát a Nemzeti Ujság sem leplezte, ám Lipthay és szerkesztőtársai március 31-én megnyugodhattak, hiszen március utolsó napján újabb királyi leirat érkezett az országgyüléshez. Az immár elfogadható feltételek mellett megalakult az első felelős magyar kormány, a miniszterek elfoglalták tárcáikat. A felelős magyar kormány megalakulásával a lap befejezettnek tekintette a békés forradalom első szakaszát, és egyértelműen fent kívánta tartani a nemzeti egységben létrejött belső nyugalmat.

A hírlap által leginkább üdvözölt fejlemény a nemzeti függetlenség, a Bécstől való függés lazítása volt. Az ország függetlensége szerintük, akárcsak a korábbi ellenzék szerint, a törvényi szabályozás tekintetében biztosítva volt az ország alkotmányában, a kétoldalú szerződésként született Pragmatica Sanctióban és az 1790. X. törvénycikkben. E dokumentumokat tekintették a magyar államiság és a nemzeti függetlenség alapjának. A lap vezércikkírója kijelentette, az 1848. márciusig regnáló magyar kormányzat tagjai ,, csak gépek voltak”, ${ }^{28}$ az új magyar kormány viszont Ausztriától függetlenül, de a birodalmi kormányzattal egyeztetve működhet. Az újra helyreállt nemzeti függetlenséget olyannyira nagy becsben tartották, hogy lehetetlennek vélték annak megsemmisítését. A forradalom utáni Pesten ugyanis március végén elterjedt egy szóbeszéd, miszerint az Oroszországba menekült Metternich fegyverrel tervezi leverni a magyar forradalmat, és visszaállítani Magyarország alávetettségét. E pletykákat megcáfolandó, a Nemzeti Ujság kijelentette: ,, amit a király megerősitett, az szent és visszavonhatatlan. "29 A forradalom után a hírlap következetesen kiállt az önálló magyar pénzügy és hadügy mellett, mondván a két ügy a „,nemzet idege és vére”. ${ }^{30}$

Az Apponyi-féle magyarországi kormányzat - melyet 1845 óta hol kisebb, hol nagyobb bírálat ért a lap részéről - tehát végérvényesen megbukott. A vagyon és a magántulajdon szentségén

\footnotetext{
${ }^{27}$ Nemzeti Ujság 1848. március 26. Magyarország és Erdély.

${ }^{28}$ Nemzeti Ujság 1848. március 23. Egyesüljünk őszintén.

${ }^{29}$ Nemzeti Ujság 1848. március 30. Hazafiak!

${ }^{30}$ Nemzeti Ujság 1848. március 30. Hazafiak!
} 
kívül a „,régi országnyomorgató rendszer” összeomlott, és minden régi törvény érvényét vesztette. 1848. április 8-án a lap azonban közölte Apponyi György levelét, melyben a leköszönt kancellár kijelentette, csakis a haza érdekeit nézte, és fogja nézni ezután is. ${ }^{31}$

Egyértelmű volt, hogy Magyarország jogainak alapja a Pragmatica Sanctio, és ugyanígy az új törvényeknek is az alapján kell állni. Ezeket az új törvényeket pedig a jelenleg is működő országgyülésnek kell meghoznia, azután viszont azonnal fel kell oszlania, a forradalom csak ez után fog véget érni. Az új országgyülést azonban már a népképviselet alapján kell megválasztani Lipthay szerint. Ez szintén nagy fordulat a lap eszmeiségét illetően, hiszen az országgyülés megnyitása pillanatában is ellenezték még a felelős kormányzás elvét és a parlamentarizmust, 1848 márciusában azonban eltűnt minden ilyenfajta eszmefuttatás a lap számaiból.

A népképviseleten kívül üdvözölték a jobbágyfelszabadítást is. Felemelték viszont hangjukat a nemesség védelme érdekében. Kiemelték, a birtokos nemesség is dicséretet érdemel, mert önként beleegyeztek az úrbéri viszonyok megszüntetésébe. Persze ehhez hozzátehetjük, hogy a nemességnek gyakorlatilag nem is volt más választása, és csak sodródtak az árral.

Habár a hírlap szerint nem szabad többet követelni a szükségesnél, a pesti forradalom sikerein túl további javaslatokkal is előállt a Nemzeti Ujság. Kifejtették, a nádort, ,, szivünk kedveltjét” helytartói hatalommal kellene felruházni, hogy a parlamentnek felelős kormány megfelelően tudjon müködni. Szorgalmazták ezen túl a postabér eltörlését, valamint a szegény nemesség adómentességének ideiglenes fenntartását. ${ }^{32}$

A politikai hírlap márciusi fordulata nem kerülte el a kortársak, például a Pesti Hirlap figyelmét sem. A korábbi ellenzéki lap állítását, miszerint a Nemzeti Ujság munkatársai konzervatívokként feküdtek le este, és radikálisként ébredtek fel másnap reggel, a lap hosszasan cáfolta. Állításuk szerint ők már 1847 októberében elváltak a konzervatívoktól, azóta pedig független álláspontot képviseltek. Ezzel együtt akkor megváltoztak céljaik is, nevezetesen: az arisztokratikus politikai befolyás mérséklése, egy képviseleti elven nyugvó, független magyar kormány felállítása. 1847 őszén valóban megfigyelhető egy váltás a politikai hírlap elveit illetően, de nem jelenthető ki egyértelműen, hogy már akkor teljesen szakítottak a konzervatívokkal.

1848 áprilisában a radikális fordulatot végrehajtó lap már nem csak a kialakult helyzetről és annak támogatásáról írt, hanem saját javaslatokkal is előállt. A Pragmatica Sanctio, és ezáltal az ország közjogi helyzetének problematikája az Ausztriának küldött piemonti hadüzenet kapcsán került ismét előtérbe. A hírlap szerint Magyarországon is múlhat, hogyan alakul a helyzet egy esetleges európai háborúban. ${ }^{33} \mathrm{Az} 1723$-as sarkalatos törvény szerint az ország köteles részt venni az olasz háborúban, de kötelességei vannak a dinasztiának is e szerződés szerint, nevezetesen az, hogy visszaszerezze a Magyar Korona jogszerinti örökségét, az újság által megnevezett al-dunai tartományokat. Ezt azonban, folytatta a cikk eddig nem tehette meg az uralkodóház a birodalom helyzetének kockáztatása nélkül. Az olasz helyzettel kapcsolatban ugyanerre a logikai síkra helyezkedett a Nemzeti Ujság: ,,... a birodalom integritását Olaszország irányában védelmezni, annyi volna, mint a dynastia és nemzetünk állását compromittálni. ${ }^{{ }_{34}} \mathrm{~A}$ szardíniai hadüzenet

\footnotetext{
${ }^{31}$ Nemzeti Ujság 1848. április 8. Apponyi György levele.

${ }^{32}$ Nemzeti Ujság 1848. március 26. Magyarország és Erdély.

${ }^{33}$ Nemzeti Ujság 1848. április 6. Magyarország és Erdély.

${ }^{34}$ Nemzeti Ujság 1848. április 6. Magyarország és Erdély.
} 
ugyanis az egész olasz nemzet hadüzenete, a magyar nemzetet pedig lehetetlen egy szintén a szabadságáért harcoló nép ellen hangolni, arra még az új magyar kormány sem lenne képes. Következésképpen, Magyarország és a magyar katonák nem hajlandóak részt venni a háborúban.

A Pragmatica Sanctióban lefektetett alapszabályok értelmezésében még tovább ment Lipthay. A felelős minisztériumok felállításával szerinte biztos alapra került az ország belső függetlensége, azonban a külső még korántsem. Magyarország ugyanis méretéhez, népességéhez és erőforrásaihoz képest az őt megilletőnél jóval kisebb súllyal bír a birodalmon belül. Mindennek az oka, hogy nem volt önálló magyar diplomácia és külpolitika, ezáltal pedig csak másodrendű nép volt a magyar Európa nemzetei között. ${ }^{35}$

Lipthay szerint vannak olyan pillanatok, amikor csak úgy lehet az ország status quo-ját biztosítani, ha az alkalmazkodik a fennálló, újonnan kialakult körülményekhez. Az új körülmények között ugyanis a sarkalatos törvények megrendültek. A főszerkesztő ezek mellett kiemelte, a magyar nemzet még ilyen körülmények között is lojális marad uralkodójához, így nem lehet hütlenséggel vádolni. Lipthay ezután ismertette a forradalom után kialakult regionális helyzetet. Szerinte Lombardia és Velence már elveszett a birodalom számára. Lengyelország visszaállításának lehetősége népszerü téma volt, így Lipthay lemondott az egykor formálisan a Magyar Korona alá tartozott Galícia, Lodoméria és Bukovina visszacsatolásáról. Ezek ismeretében három pontos követelést tett közzé a hírlap hasábjain. Követelte a Magyar Birodalom elnevezést az Ausztriai Birodalom helyett; követelte a királyi udvar Buda-Pestre költöztetését; és végül követelte egy új örökösödés rend bevezetését. Ám, hogy legutóbbin mit értett, azt nem részletezte a cikkíró. Ezek rendkívül radikális javaslatok voltak a korban, megvalósításukra pedig igen csekély esély mutatkozott.

Ezzel párhuzamosan természetesen önálló magyar külpolitikát és hadügyet irányzott elő a Nemzeti Ujság. A lap munkatársai szerint Olaszország csupán dicstelen temető lehetne a katonák számára, ráadásul a magyar bakák Itáliába küldése esetén az ország határai védtelenek maradnának. A bécsi kormány intézkedései veszélyeztetik Magyarország stabilitását, ezzel együtt pedig a dinasztia érdekeit is. Ezzel kapcsolatban jegyezte meg a lap kritikusan, hogy hiába van Magyarországnak kormánya, ha az nem szólal fel az ország érdekében. Ráadásul az országgyűlés is utolsó fázisában van, hamarosan feloszlik, ,, a legjobb lesz már egy uttal, ha bevárják, míg az orosz Pozsonyból szét nem kergeti őket. "'36

A lap tehát, bár üdvözölte az új törvényeket, az országgyülés feloszlását még korainak vélte. Ugyanis hírek keringtek arról, hogy az orosz hadsereg mozgolódik. Az orosz veszély és a pánszlávizmustól való félelem annyira rémisztő volt Lipthay és a szerkesztők számára, hogy még az újonnan alakult magyar kormány bírálatától sem rettentek vissza. Szerintük ugyanis a rendek és a kormány semmit nem tett a nemzet védelmének biztosítása érdekében. Javaslatuk szerint proklamációt kell eljuttatni az oroszok számára, melyben az országgyülés hitet tesz az al-dunai népek és a lengyelek védelme mellett. ${ }^{37} \mathrm{~A}$ diétának napokon belül cselekednie kell, jelentették ki, vagy az egész országgyülés eddigi munkája hiábavaló volt. „, A hanyatló császárság homályában, nem hagyhatjuk leáldozni a magyar korona fényét. " ${ }^{38}$ A határ védelmével és a megfelelő védelmi

\footnotetext{
${ }^{35}$ Nemzeti Ujság 1848. április 11. Nézzünk elöre.

${ }^{36}$ Nemzeti Ujság 1848. április 11. Magyarország és Erdély.

${ }^{37}$ Nemzeti Ujság 1848. április 9. Magyarország és Erdély.

${ }^{38}$ Nemzeti Ujság 1848. április 11. Magyarország és Erdély.
} 
intézkedésekkel kapcsolatos gondolataik komolyságát jelzi egy 1848. április 23-i cikk is, melyben a pesti színész Egresi Gábor, aki a radikális pesti ifjúság köreihez tartozott, a nemzetőrség fegyverzetéről és egyenruhájáról értekezett, mindenekelőtt az olcsóságot és a nemzetiességet hangsúlyozva. ${ }^{39}$

Természetesen a belpolitikát illetően is több javaslattal állt elő a Nemzeti Ujság. Üdvözölte az áprilisi törvényeket, de a feladatot még nem tekintette befejezettnek. „,Az alapköveket letettük ugyan már; de még az épület nem áll. " ${ }^{40}$ - vélték. A legnehezebbnek az úrbéri viszonyok megszüntetését, azaz a kötelező örökváltság véghez vitelét tartották, melyet javaslatuk szerint egy új adónem kivetésével lehetett volna csak finanszírozni. ${ }^{41}$

Április hónap folyamán többször hangot adott a lap annak az elképzelésének, hogy a kormánynak szüksége van egy hivatalos lapra, melyen keresztül intézkedéseiről értesíti az érdeklődő közönséget. Lipthay lapja három pontban fogalmazta meg ezzel kapcsolatos javaslatait. Elsősorban a nemzetet mindenről értesíteni kell; az értesítéseknek részletesnek, minden adatra kiterjedőnek, és nem utolsó sorban a lehető legpontosabbnak kell lenniük. ${ }^{42}$

A szerkesztő a lap hasábjain kifejtette, az abszolutizmus, habár ,,meghajlott, megtörve nincs”. Ennek megfelelően a bécsi abszolutista bürokráciával való szembenállás figyelhető meg az államadósság kérdésével kapcsolatos április 20 -i cikkben is. A bécsi vezetés elképzelése szerint a részlegesen önállósuló Magyar Királyságnak arányos mértékben át kellett volna vállalnia a birodalmi államadósság egy részét. Ez az állásfoglalás teljes elutasításban részesült a hírlap hasábjain. Az ezt tárgyaló cikk szerint az államadósság egy részének átvállalásával lehetetlenné vált volna az ország anyagi függetlenségének kialakítása és jólétének növelése. Lipthay ráadásul azt fejtegette, hogy a magyar függetlenségnek nem ideológiai, hanem anyagi-pénzügyi és gazdasági alapjai voltak, az elsődleges cél az volt, hogy az ország megszabaduljon a bécsi gyarmati rendszertől. ${ }^{43}$

A szerkesztő szerint az adósságot nem lehet igazságos arányban átvállalni, hiszen a hitelek felvétele és felhasználása Magyarország megkérdezése és beleegyezése történt és folyt. Az adósság átvállalásával a két birodalomrész közötti békés együttműködés véget érne, ez esetben pedig „, a nemzet, a 15 millió nép, mint egy ember talpra fog állani!’. ${ }^{44} \mathrm{~A}$ fenyegető hangnem tanúbizonysága szerint úgy tűnik, Lipthay nem zárta ki a nemzet szembefordulását Béccsel sem, és nemzet alatt már nem csak a nemességet értette.

A hírlapnak a pesti forradalom alkalmával gyökeresen megváltozott politikai állásfoglalása a vezércikkeken túl több kisebb cikkben is megfigyelhető. Április elején például megjelent egy katolikus pap által írt felhívás a lapban, mely a papoknak a templomon kívül világi öltözetet, valamint ,természet adta” arcszőrzetük meghagyását kérte. ${ }^{45}$ Április 9-én az újság felhívást tett közé a Nemzeti Kör következő gyülésével kapcsolatban, valamint ugyanebben a számban felszólította a fôváros lakosságát egy, a pesti forradalom emlékére állítandó műemlék pénzügyi

\footnotetext{
${ }^{39}$ Nemzeti Ujság 1848. április 23. Pest April 21-kén.

${ }^{40}$ Nemzeti Ujság 1848. április 13. Magyarország és Erdély.

${ }^{41}$ Nemzeti Ujság 1848. április 13. Javaslat.

${ }^{42}$ Nemzeti Ujság 1848. április 21. Adatokat kérünk alázatosan.

${ }^{43}$ Nemzeti Ujság 1848. április 20. Pest, April 19-kén.

${ }^{44}$ Nemzeti Ujság 1848. április 20. Pest, April 19-kén.

${ }^{45}$ Nemzeti Ujság 1848. április 6. Fölszólitás a magyar papsághoz.
} 
támogatására. Április 7-én pedig a népgyülés intézménye és a népképviseleti rendszer legitimitását boncolgatta. A lap szerint a népképviselet az emberiség ősi jogai közé tartozik, a különbség pedig a korábbi gyülésekhez képest az, hogy immár az egész népesség képviseltetni fogja magát az országgyülésen. Kiemelte, a nép képes önmagát kormányozni. ${ }^{46}$

A Nemzeti Ujság életében 1848. április 26-án újabb nagy változás történt: több mint három év után Lipthay Sándor lemondott főszerkesztői pozíciójáról. Döntését egészségi állapotával, valamint „,más viszonyokkal” magyarázta. Lemondásának oka ezzel szemben minden bizonynyal az volt, hogy a Nemzeti Ujság húsvét előtti, április 23-i számában két kompromittáló cikk is megjelent. A korábbi főszerkesztő mindkettőt elutasította. Az egyik szerint az adminisztrátori rendszert azért vezette be az előző kormányzat, hogy az államadósság egy részét Magyarország elvállalja. A Külföld című rovatban megjelent írás meglepőbb. Lipthay szerint is csak ,tévedésböl becsuszott”. Történt ugyanis, hogy Karslruheban munkások tüntettek jobb életkörülményekért és a köztársaság mellett. A rovat szerkesztőjének kommentárja szerint: , ,... addig a kényelemhez a statusban senkinek joga nincs, mig a statusban van egyetlen ember a ki éhezik. "47 A szocializmus eszméi felé történő közelítés a Nemzeti Ujság főszerkesztője számára nem volt vállalható. Lipthay lemondásával véget ért egy rövid, ám annál izgalmasabb korszak a Nemzeti Ujság életében, sőt, véget ért maga a Nemzeti Ujság is, 1848 májusától 1848 december végi megszünéséig a lap Illucz Oláh János szerkesztésében, Nemzeti cím alatt jelent meg.

Összességében kijelenthető, hogy a hírlap szerkesztői és kiadója nem utasította el mereven a haladás liberálisok által propagált eszméjét, igyekezett alkalmazkodni az új viszonyokhoz. Az alapvetően konzervatív politikai hírlap 1845 és 1847 között folyamatosan távolodott a bécsi abszolutista udvar hivatalos álláspontjától. 1848 márciusában a kortársak számára is érthetetlen eszmei fordulatot végrehajtva ráadásul teljes mellszélességgel beálltak az új rendszer támogatói mellé; sőt, a Nemzeti Ujság volt az első sajtótermék, mely megtette ezt. Ennek egyik oka lehet a forradalmi helyzettel való teljes azonosulás, amelyet alátámaszt, hogy 1848 márciusában a márciusi ifjak többen is csatlakoztak közül a hírlap munkatársaihoz. Ezen ifjak közé tartozott például Majer Károly, aki a lap országgyülési megfigyelője lett, Birányi-Schultz Ákos, akinek a pesti forradalom első leírását köszönhetjük, vagy az alapvetően konzervatív, de a márciusi ifjakhoz csatlakozott Bulyovszki Gyula is. Az ifjak számára vonzerőt jelenthetett a lap megváltozott álláspontja, és talán úgy gondolhatták, hosszabb távon a hírlapot saját kezeikbe vehetik.

A pálfordulás egy másik oka lehet, hogy a lap és munkatársai féltek a forradalom további radikalizálódásától, és az új rendszer támogatásával próbáltak annak gátat szabni. Valószínű, hogy mindkét tényező szerepet játszott az eszmei fordulatban, és a konzervatív eszmék fó irányvonalától már korábban eltávolodó lap így igyekezett megmenekülni a háttérbe szorulástól.

\footnotetext{
${ }^{46}$ Nemzeti Ujság 1848. április 7. Népgyülések.

${ }^{47}$ Nemzeti Ujság 1848. április 23. Külföld.
} 


\section{FELHASZNÁLT IRODALOM}

BÉNYEI MIKLÓs (1994): Reformkori országgyülések a sajtószabadságról. Debrecen, MTA Debreceni Akadémiai Bizottság, 1994.

BuZINKAY GÉZA (2017): A magyar sajtó és újságírás története a kezdetektől a rendszerváltásig. Budapest, Wolters Kluwer Kft.

DEÁK ÁGNES (2010): A koronás Wargha - Egy kettös ügynök Kossuth és a császári rendörség szolgálatában. Budapest, Akadémiai Kiadó.

DeZsÉNYi Béla (1941): Nemzeti Ujság 1840-1848. Nyolc év egy konzervativ hirlap életéböl. Budapest. Különlenyomat a „Regnum Egyháztörténeti Évkönyv” 1940-41. kötetéből.

Diószegi István (1997): A hatalmi politika másfél évszázada 1789-1939. Budapest. História Könyvtár, Monográfiák 4.

DöBÖR ANDRÁs (2018): Sajtópolitika és politikai sajtó Magyarországon (1780-1840). Budapest, Gondolat Kiadó.

GERGELY ANDRÁS (szerk.) (2003): Magyarország története a 19. században. Budapest, Osiris Kiadó. Idősb Szőgyény-Marich László országbiró emlékiratai (1903) I. kötet. Budapest, Hornyánszky Viktor cs. és kir. Könyvnyomdája.

KÓKAY GYÖRGY (szerk.) (1979): A magyar sajtó története. I. kötet. Budapest, Akadémiai Kiadó. SzINNYEI JózSEF (1897): Magyar írók élete és munkái. V. kötet. Budapest, Hornyánszky Viktor Könyvkiadóhivatala.

VelKey FerenC (1998): „Párt! Szólj, ki vagy?” Politikai önmeghatározások 1846-47 pártprogramjaiban. In MOLNÁR ANDRÁS (szerk.): Az ellenzéki nyilatkozat és a kortársak. Zalaegerszeg, Zalaegerszegi Szabadelvü Kör.

\section{Lapszámok}

Nemzeti Ujság 1845. január 2. Irány és tájékozás.

Nemzeti Ujság 1845. január 5. Politikai pártok.

Nemzeti Ujság 1846. június 18. - július 14. Politikai programm.

Nemzeti Ujság 1846. október 8-23. A conservativ ügy körüli közvetlen teendők.

Nemzeti Ujság 1847. január 1. Adó és urbérváltság.

Nemzeti Ujság 1847. január 7. Adó és urbérváltság.

Nemzeti Ujság 1847. február 18. Ábránduljunk ki honfiak!

Nemzeti Ujság 1847. március 9. Szózat. 
Nemzeti Ujság 1847. április 2., 4. Az elemi iskolák ügye.

Nemzeti Ujság 1847. április 22. - július 29. Nyilt levelek Lipthay Sándorhoz.

Nemzeti Ujság 1847. május 20. Örökváltság.

Nemzeti Ujság 1847. május 28., június 1., június 8. Örökváltság.

Nemzeti Ujság 1847. július 30. Zsidóügy.

Nemzeti Ujság 1847. augusztus 15. A magyarhoni gazdászat előmozditásának némi eszközei.

Nemzeti Ujság 1847. november 5-14. Memorandum.

Nemzeti Ujság 1847. november 28. Országgyülési szabad hirlapok.

Nemzeti Ujság 1848. március 19. Battyány-Kossuth ministerium.

Nemzeti Ujság 1848. március 21. Magyarország és Erdély

Nemzeti Ujság 1848. március 23. Egyesüljünk őszintén.

Nemzeti Ujság 1848. március 24. Figyelmeztetésünk.

Nemzeti Ujság 1848. március 26. Magyarország és Erdély

Nemzeti Ujság 1848. március 28. Inditvány.

Nemzeti Ujság 1848. március 30. Hazafiak!

Nemzeti Ujság 1848. március 31. A P. Hirlapnak baráti értesitésül; Fontos körülmény e kritikus időkben.

Nemzeti Ujság 1848. április 2. Örömhir; Állapotunk.

Nemzeti Ujság 1848. április 4. A vörös szin; Értsük meg s kiméljük egymást.

Nemzeti Ujság 1848. április 6. Magyarország és Erdély; Fölszólitás a magyar papsághoz.

Nemzeti Ujság 1848. április 7. Népgyülések.

Nemzeti Ujság 1848. április 8. Apponyi György levele.

Nemzeti Ujság 1848. április 9. Magyarország és Erdély

Nemzeti Ujság 1848. április 11. Nézzünk elöre.

Nemzeti Ujság 1848. április 13. Magyarország és Erdély

Nemzeti Ujság 1848. április 20. A társasági elemek s revolutiok; Pest April 19-kén.

Nemzeti Ujság 1848. április 21. Pest April 21-kén; Magyarország és Erdély; Adatokat kérünk alázatosan.

Nemzeti Ujság 1848. április 23. Külföld.

Nemzeti Ujság 1848. március 21. Rendkivüli lap. 